\title{
A Study of Relationships Between Single Nucleotide Polymorphisms from the Growth Hormone-Insulin-like Growth Factor Axis and Bone Mass: the Hertfordshire Cohort Study
}

\author{
ELAINE M. DENNISON, HOLLY E. SYDDALL, KAREN A. JAMESON, AVAN AIHIE SAYER, TOM R. GAUNT, \\ SANTIAGO RODRIGUEZ, IAN N.M. DAY, CYRUS COOPER, MIRJAM A. LIPS, and the Hertfordshire Cohort Study Group
}

\begin{abstract}
Objective. We sought evidence of association of candidate single nucleotide polymorphisms (SNP) within the growth hormone-insulin-like growth factor 1 (IGF1) axis, largely selected on the basis of functional data available at the time of our study, with adult bone mass.

Methods. Four hundred ninety-eight men and 468 women aged 59-71 years were recruited. A lifestyle questionnaire was administered, and bone mineral content (BMC) and bone mineral density (BMD) were measured at the lumbar spine and femoral neck. Two hundred fifty-four men and 271 women had repeat bone densitometry 4 years later. DNA was obtained from whole blood samples using standard extraction techniques. Single nucleotide variants in the growth hormone releasing hormone gene (GHRH, G/A 223 Phe75Leu, rs4988492), growth hormone releasing hormone receptor gene (GHRHR, G/A 217, Ala57Thr, rs4988496), the growth hormone secretagogue receptor gene (GHSR, T/C, Gly57Gly, rs495225), and the growth hormone receptor gene (GHR, T/G, noncoding, rs2940944) were analyzed.

Results. In both sexes, allelic variation in the gene encoding $G H R H$ was associated with BMC and BMD at the proximal femur and lumbar spine, with results generally stronger in women. In women, the mean BMC lumbar spine within the GHRH 11 genotype was $56.9 \mathrm{~g}$, while that of the GHRH 12 genotype was $68.4 \mathrm{~g}$ [p $<0.001$, fully adjusted for age, body mass index, cigarette and alcohol consumption, dietary calcium intake, physical activity, years since menopause, and hormone replacement therapy (HRT) use]; corresponding figures for BMD lumbar spine (GHRH 11 genotype) were $0.96 \mathrm{~g} / \mathrm{cm}^{2}$ versus $1.10 \mathrm{~g} / \mathrm{cm}^{2}$ ( $\mathrm{p}<0.001$ fully adjusted).

Conclusion. We have demonstrated a relationship between allelic variation in the gene encoding GHRH and bone density; we welcome attempts at replication in other populations. (First Release June 1 2009; J Rheumatol 2009;36:1520-6; doi:10.3899/jrheum.081061)
\end{abstract}

Key Indexing Terms:

BONE COHORT GENE GROWTH HORMONE EPIDEMIOLOGY

From MRC Epidemiology Resource Centre, University of Southampton, Southampton General Hospital, Southampton; Bristol Genetic Epidemiology Laboratories (BGEL) and MRC Centre for Causal Analyses in Translational Epidemiology (CAITE), Department of Social Medicine, University of Bristol, Bristol, UK

Supported by grants from the Arthritis Research Campaign and the Medical Research Council.

E.M. Dennison, PhD, Reader in Rheumatology; H.E. Syddall, MSc, Medical Statistician; K.A. Jameson, MSc, Medical Statistician; A. Aihie Sayer, PhD, Professor of Geriatrics, MRC Epidemiology Resource Centre, University of Southampton, Southampton General Hospital; T.R. Gaunt, PhD, Research Fellow; S. Rodriguez, PhD, Research Fellow; I.N.M. Day, PhD, Professor of Human Genetics, BGEL and MRC Centre for CAITE, Department of Social Medicine, University of Bristol; C. Cooper, MD, Professor of Rheumatology; M.A. Lips, MD, Research Student, MRC Epidemiology Resource Centre, University of Southampton, Southampton General Hospital.

Address correspondence to Dr. E.M. Dennison, MRC Epidemiology

Resource Centre, Southampton General Hospital, Southampton

SO16 6YD, England.E-mail: emd@mrc.soton.ac.uk

Accepted for publication February 12, 2009.
Twin and family studies confirm an inherited contribution to peak bone mass ${ }^{1-4}$, and various candidates have been proposed for the genetic regulation of bone mineral, including the genes for the vitamin $\mathrm{D}$ receptor (VDR), the estrogen receptor, and type I collagen (COLIA1) ${ }^{5}$. However, polymorphisms in these genetic loci explain only a small portion of the observed variance in bone mass in the general population ${ }^{6,7}$. Growth hormone (GH) stimulates linear growth in childhood and bone remodeling throughout life. The biological function of the pulsatile pattern of GH secretion is unknown, but the amplitude of GH peaks and total integrated GH concentration both correlate with height during childhood $^{8}$, suggesting that total GH concentration may be an important determinant of skeletal growth. Although the role of GH in the risk of osteoporosis is unclear, GH deficiency is associated with low adult bone mineral density $(\mathrm{BMD})^{9-11}$, but this is often difficult to correct with $\mathrm{GH}$ 
treatment, in spite of increase in bone turnover. While case control studies show lower circulating insulin-like growth factor (IGF)-1 levels in patients with osteoporosis than normal controls ${ }^{12}$, the administration of $\mathrm{GH}$ to elderly men and women has produced generally negative results ${ }^{13-15}$. We have previously demonstrated relationships between single nucleotide polymorphisms (SNP) in the growth hormone gene and adult bone mass in a UK population ${ }^{16}$. Here we sought to extend our investigation of the growth hormone-insulin-like growth factor axis by studying associations between candidate polymorphisms of the growth hormone releasing hormone $(G H R H)$, growth hormone secretagogue receptor $(G H S R)$, growth hormone receptor $(G H R)$, and $I G F-I R$ genes. The candidate polymorphisms adopted in this study were chosen so as to represent various dynamic components of the growth hormone regulatory system, the majority of which were postulated to have functional consequences.

\section{MATERIALS AND METHODS}

In our study, which was designed to examine the relationship between growth in infancy and the subsequent risk of osteoporosis, the selection procedure was as follows: using the National Health Service Central Registry at Southport, and Hertfordshire Family Health Service Association, we traced men and women who were born during 1931-39 in Hertfordshire, and still lived there during the period 1998-2003 ${ }^{17}$. After obtaining written permission from each subject's general practitioner (GP), we approached each person by letter, asking him or her if they would be willing to be contacted by one of our research nurses. If subjects agreed, a research nurse performed a home visit and administered a structured questionnaire. This included information on socioeconomic status, medical history, drug history, cigarette smoking, alcohol consumption, and reproductive variables in women.

At clinic, height was measured to the nearest $0.1 \mathrm{~cm}$ using a Harpenden pocket stadiometer (Chasmors Ltd, London, UK) and weight to the nearest $0.1 \mathrm{~kg}$ on a SECA floor scale (Chasmors Ltd). Venous whole blood samples were taken at this clinic visit.

Eligible subjects were then invited to book a return visit for bone density measurements. Individuals taking drugs known to alter bone metabolism (such as bisphosphonates) were excluded from this part of the study, although women taking hormone replacement therapy (HRT) were allowed to participate. There were no other exclusion criteria. BMD was measured in each subject, by dual energy X-ray absorptiometry (DEXA) at the lumbar spine and proximal femur (neck, total, intertrochanteric and trochanteric regions, Wards triangle) using a Hologic QDR 4500 instrument (Vertec Scientific, Reading). Measurement precision error, expressed as coefficient of variation, was $1.55 \%$ for lumbar spine BMD, $1.45 \%$ for total femur, and $1.83 \%$ for femoral neck BMD for the Hologic QDR 4500; these figures were obtained by 25 volunteers who were not part of the study undergoing 2 scans on the same day, getting on and off the table between examinations. Short-term ( 2 month) precision error for the QDR 4500 was less than $1 \%$ for both sites (manufacturers' figures). A total of 498 men and 468 women completed a home questionnaire, attended clinic, and underwent a bone density test.

In 2004-2005, a followup study was performed. The family doctors of participants in the baseline survey were contacted to ask if we could approach their patients again. Of the original 498 men and 468 women who had undergone a DEXA scan, 8 had died, 6 had moved away, we were unable to obtain GP permission to approach 4 people, 47 were no longer on family doctor lists, and 17 were unavailable. Hence, we were able to invite 437 men and 447 women to take part in the followup study. Of these, 322 men $(74 \%)$ and 320 women $(72 \%)$ agreed to attend a followup clinic, held at Welwyn Garden City, where BMD measurements of the lumbar spine and total femur were repeated, enabling calculation of annualized bone loss rates at these sites.

Genomic DNA was extracted from $5 \mathrm{ml} \mathrm{K-EDTA} \mathrm{venous} \mathrm{blood,} \mathrm{quan-}$ tified by picoGreen assay and concentrations equalized. Longterm stock DNA aliquots were laid down and working 96-well plates of DNA dilutions to $7 \mathrm{ng} / \mu 1$ prepared. Degenerate oligo primer amplifications (DOP-DNA) were made from dilution plates in order to conserve stock DNA and 96 or 384-well polymerase chain reaction (PCR) were performed from DOP-DNA representing $0.07 \mathrm{ng}$ of original genomic DNA. Three hundred eighty-four-well allele-specific PCR (using flanking primers and internal allele-specific primers) in conjunction with 384-well microplate array diagonal gel electrophoresis (MADGE), fluorescent image screening, and PhoretiX gel image analysis were used for SNP analyses.

Single nucleotide variants in the GHRH gene (GHRH SNP, G/A 223 Phe75Leu, rs4988492), GHRHR gene (GHRHR SNP, G/A 217, Ala57Thr, rs4988496), the GHSR gene (GHSR SNP, T/C, Gly57Gly, rs495225), and the GHR gene (GHR SNP, T/G, noncoding, rs2940944) were analyzed. Alleles with major and minor allelic frequencies were termed 1 and 2 respectively, resulting in genotypes 11, 12, 22. Genotypes 12 and 22 were combined in case of low frequency of the 2 allele. Figure 1 shows the SNP studied.

Analyses were conducted separately for men and women using STATA 8. The relationship between each continuously distributed phenotype variable and each SNP was explored using both analysis of variance and linear regression models. Analyses were conducted with and without adjustment for age, body mass index (BMI), typical activity level, dietary calcium intake, smoking status, alcohol intake, current social class, and menopausal status for women.

Ethical permission for the study was granted by the East and North Hertfordshire Ethical Committees. All participants gave written informed consent.

\section{RESULTS}

The characteristics of the study population at baseline are displayed in Table 1 . The mean age of the men and women studied was 64.8 and 66.3 years, respectively. Thirty-four percent of the men and $62 \%$ of the women had never smoked, while $52 \%$ of the men (28\% of the women) and $15 \%$ of the men (10\% of the women) were ex-smokers and current smokers, respectively. Four percent of men and $18 \%$ of women were non-drinkers, while $21 \%$ of men and $12 \%$ of women were moderate drinkers (11-21 and 8-14 units of alcohol per wk respectively, 1 unit being a single glass of wine or a single measure of spirits). Twenty-five percent of men and $3 \%$ of women consumed greater than the recommended number of units of alcohol per week ( $\geq 22$ units per wk for men, $\geq 15$ units per wk for women). Hardy-Weinberg equilibrium was confirmed for all genotypes studied.

When the characteristics of participants who attended the followup clinic were compared with those who did not, the following differences were apparent. Participants who completed the study were less likely to be current smokers at the initial clinic visit $(9.7 \%$ vs $17.3 \%, p=0.001)$, were of higher social class $(41.7 \%$ listed as social class I-IIINM vs $33 \%$ of non-completers, $\mathrm{p}=0.03$ ) and had a lower BMI at baseline [26.5 (standard deviation, SD 1.2) vs 27.2 (SD 1.2), $\mathrm{p}=0.01$ )].

Table 2 displays the relationships between the $G H R H$ Personal non-commercial use only. The Journal of Rheumatology Copyright @ 2009 . All rights reserved. 


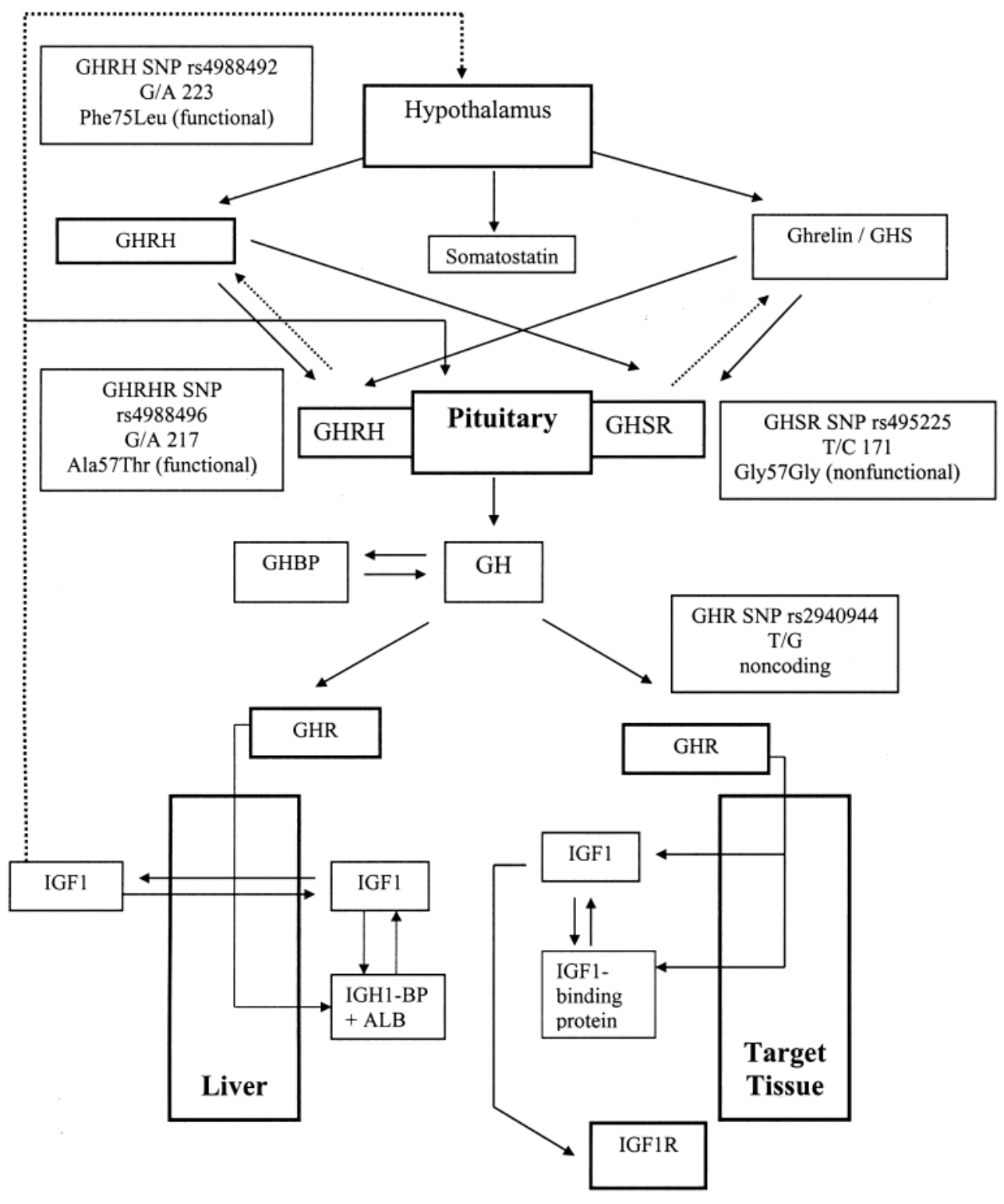

Figure 1. The GH-IGF1 axis with SNP studied marked.

SNP and bone mass and loss. Among men, GHRH 12 heterozygotes had higher BMC and BMD at the total femur than GHRH 11 homozygotes (test for trend BMC $\mathrm{p}=0.02$, BMD $\mathrm{p}=0.12$, fully adjusted for age, social class, BMI, physical activity, calcium intake, cigarette and alcohol consumption). Similar relationships were observed in women at the lumbar spine (mean BMC lumbar spine GHRH 11 genotype $=56.9 \mathrm{~g}, G H R H 12 / 22$ genotype $=68.4 \mathrm{~g}, \mathrm{p}<0.001$, fully adjusted; mean BMD lumbar spine $G H R H 11$ genotype $=0.96 \mathrm{~g} / \mathrm{cm}^{2}$, GHRH 12/22 genotype $=1.10 \mathrm{~g} / \mathrm{cm}^{2}, \mathrm{p}<$ 0.001 fully adjusted).

Among men, individuals of genotype GHSR 22 had lower BMC and BMD at the lumbar spine than those of
GHSR 11 or GHSR 12 genotype (test for trend BMC $\mathrm{p}=$ 0.09 , BMD $\mathrm{p}=0.12$, fully adjusted); males of genotype GHR 22 had higher BMC and BMD at the lumbar spine than those of GHR 11 or GHR 12 genotype (test for trend BMC $\mathrm{p}=0.05 ; \mathrm{BMD} \mathrm{p}=0.03$, fully adjusted). No such relationships were observed among women. No consistent associations with bone mass change were found for any of the other SNP studied. Finally, while significant relationships were seen between lumbar spine area and GHRH ( $\mathrm{p}=0.04$, test for trend, fully adjusted for age, social class, BMI, physical activity, calcium intake, cigarette and alcohol consumption), there were no other significant associations of genotype with body size. 
Table 1. Summary characteristics of study participants.

\begin{tabular}{|c|c|c|}
\hline $\begin{array}{l}\text { Characteristic } \\
\text { Mean (SD) unless stated otherwise }\end{array}$ & $\begin{array}{c}\text { Men } \\
(\mathrm{n}=498)\end{array}$ & $\begin{array}{l}\text { Women } \\
(\mathrm{n}=468)\end{array}$ \\
\hline Age, yrs & $64.8(2.5)$ & $66.3(2.6)$ \\
\hline BMI, $\mathrm{kg} / \mathrm{m}_{2}^{\mathrm{a}}$ & $26.6(1.1)$ & $26.9(1.2)$ \\
\hline Current smokers, n (\%) & $73(14.7)$ & $45(9.6)$ \\
\hline Alcohol consumption, units per week ${ }^{b}$ & $10.0(3.0,22.5)$ & $2.5(0.5,7.0)$ \\
\hline Dietary calcium, mg/day ${ }^{\mathrm{a}}$ & $1219(1.3)$ & $1085(1.3)$ \\
\hline Habitual activity, $\%^{\mathrm{c}}$ & 64 & 61.3 \\
\hline Current manual social class IIIM-V $\mathrm{V}^{\mathrm{d}}, \mathrm{n}(\%)$ & $193(38.8)$ & $286(61.1)$ \\
\hline Current non-manual social class I-IIIN ${ }^{\mathrm{d}}, \mathrm{n}(\%)$ & $277(55.6)$ & $182(38.9)$ \\
\hline$\leq 15$ yrs since menopause, $\mathrm{n}(\%)$ & & $186(39.8)$ \\
\hline$>15$ yrs since menopause, $\mathrm{n}(\%)$ & & $165(35.3)$ \\
\hline Hysterectomy, n (\%) & & $114(24.4)$ \\
\hline Current HRT use, n (\%) & & $79(16.9)$ \\
\hline Lumbar spine $\mathrm{BMD}, \mathrm{g} / \mathrm{cm}^{2 \mathrm{e}}$ & $1.08(0.16)$ & $0.96(0.17)$ \\
\hline Lumbar spine BMC, $\mathrm{g}^{\mathrm{e}}$ & $77.4(15.6)$ & $57.2(13.2)$ \\
\hline Lumbar spine bone loss, $\%$ change/yr & $\begin{array}{c}0.65(0.89) \\
{[\mathrm{n}=275]}\end{array}$ & $\begin{array}{c}0.33(1.49) \\
{[\mathrm{n}=292]}\end{array}$ \\
\hline Total femoral BMD, $\mathrm{g} / \mathrm{cm}_{2}{ }^{\mathrm{e}}$ & $1.04(0.13)$ & $0.90(0.13)$ \\
\hline Total femoral BMC, $\mathrm{g}^{\mathrm{e}}$ & $48.4(8.1)$ & $32.5(5.8)$ \\
\hline Total femoral bone loss, $\%$ change/yr & $\begin{array}{c}-0.09(0.70) \\
{[\mathrm{n}=276]}\end{array}$ & $\begin{array}{c}-0.55(1.20) \\
{[\mathrm{n}=289]}\end{array}$ \\
\hline GHRH 11 genotype $^{\mathrm{f}}, \mathrm{n}(\%)$ & $468(94.0)$ & $437(93.4)$ \\
\hline GHRH 12 genotype $^{\mathrm{f}}, \mathrm{n}(\%)$ & $18(3.6)$ & $14(3.0)$ \\
\hline GHSR 11 genotype $^{\mathrm{g}}, \mathrm{n}(\%)$ & $234(47.0)$ & $232(49.6)$ \\
\hline GHSR 12 genotype $^{\mathrm{g}}, \mathrm{n}(\%)$ & $162(32.5)$ & $173(37.0)$ \\
\hline GHSR 22 genotype $^{\mathrm{g}}, \mathrm{n}(\%)$ & $39(7.8)$ & $29(6.2)$ \\
\hline GHR 11 genotype $^{\mathrm{h}}, \mathrm{n}(\%)$ & $133(26.7)$ & $112(23.9)$ \\
\hline GHR 12 genotype $^{\mathrm{h}}, \mathrm{n}(\%)$ & $247(49.6)$ & $242(51.7)$ \\
\hline GHR 22 genotype $^{\mathrm{h}}, \mathrm{n}(\%)$ & $107(21.5)$ & $94(20.1)$ \\
\hline
\end{tabular}

${ }^{\mathrm{a}}$ Geometric mean (SD). ${ }^{\mathrm{b}}$ Median (IQR) among drinkers. 20 men and 86 women stated that they did not drink alcohol. ${ }^{\mathrm{c}}$ Standardized score ranging $0-100$ derived from frequency of gardening, housework, climbing stairs, and carrying loads in a typical week. Higher scores indicate greater level of activity. ${ }^{\mathrm{d}}$ Social class was unclassified for 28 men. I-IIIN and IIIM-V denote classes 1 to 3 (non-manual), and 3 (manual) to 5, of the 1990 OPCS Standard Occupational Classification scheme for occupation and social class. Social class was identified on the basis of own current or most recent full-time occupation for men and never-married women, but on the basis of the husband's occupation for ever-married women. ${ }^{\mathrm{e}}$ One man was not scanned at the lumbar spine. Three men and 1 woman were not scanned at the hip. ${ }^{\mathrm{f}}$ GHRH genotype was unavailable for 12 men and 17 women. ${ }^{\mathrm{g}}$ GHSR genotype was unavailable for 63 men and 34 women. ${ }^{\mathrm{h}}$ GHR genotype was unavailable for 11 men and 20 women. SD: standard deviation; BMI: body mass index; BMD: bone mineral density; BMC: bone mineral content; IQR: interquartile range.

Table 2. Association of GHRH SNP with bone mass in a cohort of Hertfordshire men and women.

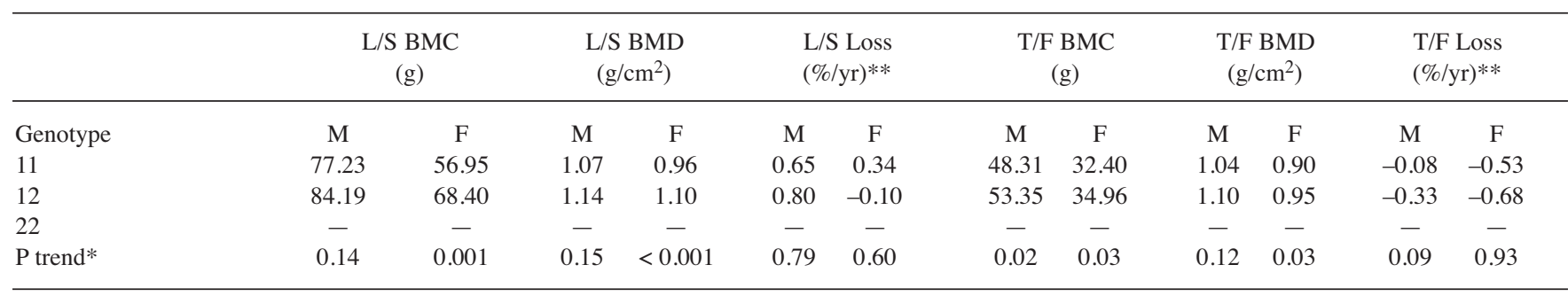

* Adjusted for age, BMI, cigarette and alcohol consumption, dietary calcium intake, physical activity, years since menopause, and HRT use. ** A negative figure denotes bone loss over the followup period. SNP: single nucleotide polymorphism; BMC: bone mineral content; BMD: bone mineral density; BMI: body mass index; HRT: hormone replacement therapy. L/S: lumbar spoine; T/F: total femur. 


\section{DISCUSSION}

We have demonstrated relationships between polymorphisms of the GHRH, GHSR and GHR genes with bone mass in a UK cohort that varied according to sex. Three recent genome wide association studies have been published ${ }^{18-20}$. Of note, these have produced rather discordant results, and indeed in conclusion one group of authors ${ }^{18}$ suggested that given the modest total variance in hip and spine bone density described by the variants reported (only $3 \%$ in their own study), many other sequence variants relevant to osteoporosis will be identified.

Our study has a number of weaknesses. The individuals recruited were selected because they had been born in Hertfordshire, and continued to live there at the age of 59-71 years, as in previous studies ${ }^{17}$. However, we have previously demonstrated that the Hertfordshire populations studied have similar smoking characteristics and bone density to national figures ${ }^{21}$, suggesting that selection bias is minimal. Clearly, our cohort size is relatively small in comparison with many genetic studies, with obvious power limitations. There was an apparent gain in bone mass at the lumbar spine over the followup period; we attribute this to osteoarthritis at that site, a well recognized phenomenon. While bone loss rates at the femoral neck were within expected limits for women (far fewer data are available for men), the modest changes in bone mass seen may have limited our ability to look for associations between genotype and bone $\operatorname{loss}^{22}$. In addition, we were able to test only 1 or very few SNP per gene, and hence this is insufficient to dismiss the possibility that these genes harbor other non-typed polymorphisms really involved in bone disease. Finally, the significance values observed might be considered quite large for a simple association study design; while this raises the possibility that the results may be attributable to chance, the purpose of our study was to perform an exploratory analysis. Attempts at replication of our findings are welcomed.

$\mathrm{GH}$ release is reciprocally regulated by 2 hypothalamic peptides, GHRH and somatostatin via specific cell surface receptors in the anterior pituitary ${ }^{23}$. GH is released in the circulation after binding of GHRH to its receptor, the GHRHR, on the pituitary. GHRH expression causes short-term decrease in GHRHR transcript levels, but longterm exposure of pituitary cells to GHRH upregulates GHRHR mRNA expression. A new natural GH-releasing peptide, ghrelin, was recently cloned and discovered to have the ability to activate the receptor for the family of synthetic GH secretagogues (GHS) ${ }^{24}$. Both ghrelin and the GHSR are expressed in the pituitary as well as in the hypothalamus. GHSR synthesis is downregulated by ghrelin and GHS, in conditions of increased GH-release.

Biologically active GH binds its transmembrane receptor, the GHR, which dimerises to activate an intracellular signal transduction pathway leading to synthesis and secretion of IGF-125. IGF-1 in turn signals the chondrocytes to differentiate, leading to cartilage formation and linear growth. IGF also has an anabolic effect on osteoblasts; it increases both cell number and stimulates matrix production $^{25}$. In addition, GH probably has effects independent of IGF-1 on bone and the epiphyseal growth plate. Both IGF-1 and $\mathrm{GH}$ have a direct effect on osteoblasts in bone resorption, though the effect of GH independent of IGF-1 seems to be more pronounced ${ }^{26}$.

The GHRH gene is found on chromosome 20; the SNP reported here has not been studied previously. Alba and Salvatori recently created a $G H R H$ gene knockout mouse that showed severe growth retardation with reduced pituitary GH mRNA and protein content, reduced serum IGF-1, and reduced liver IGF-1 mRNA, similar to the phenotype of mice with mutated $G H R H R^{27}$. In our cohort, the 2 allele of the GHRH SNP was associated with both higher BMC and BMD, which suggest that this SNP may enhance GHRH levels and consequently GH/IGF-1 secretion. The sexual dimorphism shown here suggests that the effect of the SNP is higher among women. This may be explained by the observation that men require a higher GHRH level to maintain $\mathrm{GH}$ secretion ${ }^{28}$, and will, consequently, be less affected by the slightly higher GH secretion associated with this SNP.

We also studied a SNP in the GHRHR that had been associated with a higher sensitivity to $\mathrm{GHRH}^{29}$. We hypothesized that this higher responsiveness to GHRH would lead to a higher BMD and BMC in individuals with the GHRHR SNP, but were unable to demonstrate any difference in BMD and $\mathrm{BMC}$ between individuals with the different genotypes of this SNP in our cohort, either due to no true effect or limited power in this sample. However, a role for the GHRHR gene in acquisition of bone mass has been proposed following recent studies of genetic syndromes of severe GH deficiency caused by a nonsense mutation in the GHRHR gene (dwarfism of Singh) ${ }^{30}$. Affected individuals have low areal BMD caused in part by their small bone size.

The GHSR gene is located on chromosome 3; the receptor has 2 subtypes produced by alternative splicing; the fully functional 1a type and the biologically inactive $1 \mathrm{~b}$ type. Receptor type 1a is widely distributed throughout the body, and it is thought the natural agonist ghrelin, produced in and secreted mainly by the stomach may have a variety of regulatory functions, including stimulation of appetite. Physiologically, ghrelin's actions oppose those of leptin. Shuto, et $a l^{31}$ found that decreased expression levels of the GHSR1 lead to decreased GH and IGF-1 values in female rats. They suggested that in female rats, compared to in male rats, ghrelin plays a more important role in the regulation of GH secretion by stimulating GHRH neurons through GHSR. Fukushima, et $a l^{32}$ recently demonstrated the presence of type 1a receptors in rat osteoblasts, and found that ghrelin stimulated cell proliferation and differentiation, increasing BMD in normal and GH deficient rats. 
The GHR gene is located on chromosome 5. There are 2 isoforms of GHR in humans, generated by retention or exclusion of exon 3 during splicing. The isoform of the GHR gene that lacks exon 3 (d3-GHR) was associated with 1.7 to 2 times more growth acceleration induced by growth hormone than the full-length isoform ${ }^{33}$. Mutations in the GHR gene have been demonstrated as the cause of Laron syndrome, also known as the growth hormone insensitivity syndrome. Several other polymorphisms have been described before, though only in association with idiopathic short stature ${ }^{34}$. A recent Canadian study found no association between the 2 most common isoforms of the GHR (exon 3 full-length and exon 3 deleted) and BMD among 368 healthy adult white women aged 18-35 years ${ }^{35}$.

Our findings of greater associations in women rather than men may reflect the sexual dimorphism apparent in the GH-IGF-1 axis. Estrogen leads to a relative resistance to the stimulatory effect of GH on IGF-1 production. Administration of oral estrogen in healthy postmenopausal women suppresses hepatic IGF-1 production and increases pituitary GH release ${ }^{36}$. Treatment of normal women with IGF-1 activates both osteoclasts and osteoblasts, but with a more pronounced effect on bone formation than bone resorption. There is also evidence to indicate that testosterone stimulates IGF-1 production and it is speculated that a certain threshold level of androgens is essential to ensure hepatic IGF-1 production ${ }^{36}$. A higher GHRH level is required to maintain $\mathrm{GH}$ secretion in men rather than women ${ }^{28}$ and the role of ghrelin in physiology may be sexually dimorphic with decreased levels of the GHSR gene in transgenic mice resulting in decreased GH and IGF-1 levels more often in female than male mice ${ }^{37}$. Estrogen levels also showed a pronounced effect on the GH/IGF-1 axis in rats; ovariectomy induced an increase in the serum IGF-1 concentration and administration of estrogen prevented increase in IGF-1 ovariectomized rats ${ }^{38}$.

We have found further evidence of a role for the GH-IGF-1 axis in the regulation of adult bone mass in late middle age, that did not appear to be mediated specifically through body size. Further work is now implicated to replicate these findings.

\section{ACKNOWLEDGMENT}

We thank the men and women who participated in the study, the general practitioners who allowed access to their patients, and the nurses and radiology staff who administered the bone density measurements. Computing support was provided by Vanessa Cox.

\section{REFERENCES}

1. Seeman E, Hopper JL, Bach LA, et al. Reduced bone mass in daughters of women with osteoporosis. N Engl J Med 1989;320:554-8.

2. Kelly PJ, Eisman JA, Sambrook PN. Interaction of genetic and environmental influences on peak bone density. Osteoporos Int 1990;1:56-60.

3. Pocock NA, Eisman JA, Hopper JL, Yeates MG, Sambrook PN,
Eberl S. Genetic determinants of bone mass in adults. A twin study. J Clin Invest 1987;80:706-10.

4. Slemenda CW, Christian JC, Williams CJ, Norton JA, Johnston CC Jr. Genetic determinants of bone mass in adult women: a reevaluation of the twin model and the potential importance of gene interaction on heritability estimates. J Bone Miner Res 1991;6:561-7.

5. Carbonell Sala S, Brandi ML. Update on genetic determinants of osteoporosis. J Endocrinol Invest 2006;30:2-7.

6. Gueguen R, Jouanny P, Guillemin F, Kuntz C, Pourel J, Siest G. Segregation analysis and variance components analysis of bone mineral density in healthy families. J Bone Miner Res 1995; 10:2017-22.

7. Ralston SH. Do genetic markers aid in risk assessment? Osteoporos Int 1998;8 Suppl:S37-42.

8. Hindmarsh P, Smith PJ, Brook CG, Matthews DR. The relationship between height velocity and growth hormone secretion in short prepubertal children. Clin Endocrinol 1987;27:581-91.

9. de Boer H, Blok GJ, van Lingen A, Teule GJ, Lips P, van der Veen EA. Consequences of childhood-onset growth hormone deficiency for adult bone mass. J Bone Miner Res 1994;9:1319-26.

10. Kaufman JM, Taelman P, Vermeulen A, Vandeweghe M. Bone mineral status in growth hormone-deficient males with isolated and multiple pituitary deficiencies of childhood onset. J Clin Endocrinol Metab 1992;74:118-23.

11. Hyer SL, Rodin DA, Tobias JH, Leiper A, Nussey SS. Growth hormone deficiency during puberty reduces adult bone mineral density. Arch Dis Child 1992;67:1472-4.

12. Clemmesen B, Overgaard K, Riis B, Christiansen C. Human growth hormone and growth hormone releasing hormone: a double-masked, placebo-controlled study of their effects on bone metabolism in elderly women. Osteoporos Int 1993;3:330-6.

13. Kassem M, Brixen K, Blum WF, Mosekilde L, Eriksen EF. Normal osteoclastic and osteoblastic responses to exogenous growth hormone in patients with postmenopausal spinal osteoporosis. J Bone Miner Res 1994;9:1365-70.

14. Marcus R, Butterfield G, Holloway L, et al. Effects of short term administration of recombinant human growth hormone to elderly people. J Clin Endocrinol Metab 1990;70:519-27.

15. Rudman D, Feller AG, Nagraj HS, et al. Effects of human growth hormone in men over 60 years old. N Engl J Med 1990;323:1-6.

16. Dennison EM, Syddall HE, Rodriguez S, Voropanov A, Day IN, Cooper C. Polymorphism in the growth hormone gene, weight in infancy, and adult bone mass. J Clin Endocrinol Metab 2004;89:4898-903.

17. Syddall HE, Aihie Sayer A, Dennison EM, Martin HJ, Barker DJP, Cooper C. Cohort profile: The Hertfordshire Cohort Study. Int J Epidemiol 2005;34:1234-42.

18. Styrkarsdottir U, Halldorsson BV, Gretarsdottir S, et al. Multiple genetic loci for bone mineral density and fractures. N Engl J Med 2008;358:2355-65.

19. Richards JB, Rivadeneira F, Inouye M, et al. Bone mineral density, osteoporosis, and osteoporotic fractures: a genome-wide association study. Lancet 2008;371:1505-12.

20. Kiel DP, Demissie S, Dupois J, et al. Genome-wide association with bone mass and geometry in the Framingham Heart Study. BMC Med Genet 2007;8 Suppl:S14.

21. Egger P, Duggleby S, Hobbs R, Fall C, Cooper C. Cigarette smoking and bone mineral density in the elderly. J Epidemiol Comm Health 1996;50:47-50.

22. Hannan MT, Felson DT, Dawson-Hughes B, et al. Risk factors for longitudinal bone loss in elderly men and women in the Framingham Osteoporosis Study. J Bone Miner Res 2000;15:710-20. 
23. Johansson AG, Lindh E, Ljunghall S. Growth hormone, insulin-like growth factor I, and bone: a clinical review. J Intern Med 1993;234:553-60.

24. Wang HJ, Geller F, Dempfle A, et al. Ghrelin receptor gene: identification of several sequence variants in extremely obese children and adolescents, healthy normal-weight and underweight students, and children with short normal stature. J Clin Endocrinol Metab 2004;89:157-62.

25. Ueland T. GH/IGF-I and bone resorption in vivo and in vitro. Eur J Endocrinol 2005;152:327-32.

26. Wang J, Zhou J, Cheng CM, Kopchick JJ, Bondy CA. Evidence supporting dual, IGF-I-independent and IGF-I-dependent, roles for $\mathrm{GH}$ in promoting longitudinal bone growth. $\mathrm{J}$ Endocrinol 2004;180:247-55.

27. Alba M, Salvatori R. A mouse with targeted ablation of the growth hormone-releasing hormone gene: a new model of isolated growth hormone deficiency. Endocrinology 2004;145:4134-43.

28. Jessup SK, Dimaraki EV, Symons KV, Barkan AL. Sexual dimorphism of $\mathrm{GH}$ regulation in humans: endogenous $\mathrm{GH}$-releasing hormone maintains basal GH in women but not men. J Clin Endocrinol Metab 2003;88:4776-80.

29. Adams EF, Symowski H, Buchfelder M, Poyner DR. A polymorphism in the growth hormone $(\mathrm{GH})$-releasing hormone $(\mathrm{GHRH})$ receptor gene is associated with elevated response to GHRH by human pituitary somatotrophinomas in vitro. Biochem Biophys Res Commun 2000;275:33-6.

30. Maheshwari HG, Bouillon R, Nijs J, Oganov VS, Bakulin AV, Baumann G. The Impact of congenital, severe, untreated growth hormone $(\mathrm{GH})$ deficiency on bone size and density in young adults: insights from genetic GH-releasing hormone receptor deficiency. J Clin Endocrinol Metab 2003;88:2614-8.
31. Shuto Y, Shibasaki T, Otagiri A, Kuriyama H, Ohata H, Tamura H. Hypothalamic growth hormone secretagogue receptor regulates growth hormone secretion, feeding, and adiposity. J Clin Invest 2002;109:1429-36.

32. Fukushima N, Hanada R, Teranishi H, et al. Ghrelin directly regulates bone formation. J Bone Miner Res 2005;20:790-8.

33. Dos SC, Essioux L, Teinturier C, Tauber M, Goffin V, Bougneres P. A common polymorphism of the growth hormone receptor is associated with increased responsiveness to growth hormone. Nat Genet 2004;36:720-4.

34. Goddard AD, Covello R, Luoh SM, et al. Mutations of the growth hormone receptor in children with idiopathic short stature. The Growth Hormone Insensitivity Study Group. N Engl J Med 1995;333:1093-8

35. Kenth G, Shao Z, Cole DEC, Goodyer CG. Relationship of the human growth hormone receptor exon 3 genotype with final adult height and bone mineral density. J Clin Endocrinol Metab 2007;92:725-8.

36. Jorgensen JO, Christensen JJ, Vestergaard E, Fisker S, Ovesen P, Christiansen JS. Sex steroids and the growth hormone/insulin-like growth factor-I axis in adults. Horm Res 2005;64 Suppl:37-40.

37. Shuto Y, Shibasaki T, Otagiri A, et al. Hypothalamic growth hormone secretagogue receptor regulates growth hormone secretion, feeding, and adiposity. J Clin Invest 2002;109:1429-36.

38. Yokose $\mathrm{S}$, Ishizuya $\mathrm{T}$, Ikeda $\mathrm{T}$, et al. An estrogen deficiency caused by ovariectomy increases plasma levels of systemic factors that stimulate proliferation and differentiation of osteoblasts in rats. Endocrinology 1996;137:469-78. 